\title{
Effect of pituitary adenylate cyclase-activating polypeptide (PACAP) on progestin biosynthesis in cultured granulosa cells from rat ovary and expression of mRNA encoding PACAP type IA receptor
}

\author{
E. Kotani, S. Usuki and T. Kubo \\ Department of Obstetrics and Gynecology, Institute of Clinical Medicine, University of Tsukuba, \\ Tennodai 1-1-1, Tsukuba-shi, Ibaraki 305, Japan
}

\begin{abstract}
The purpose of this study was to detect the presence of mRNA encoding pituitary adenylate cyclase-activating polypeptide (PACAP) type I receptor in granulosa cells from rat ovary and to examine the effect of PACAP on progestin biosynthesis. mRNA was isolated from granulosa cells from the ovaries of immature rats treated with pregnant mares' serum gonadotrophin. The technique of reverse transcription and polymerase chain reaction with primers specific to PACAP type I receptor were used to demonstrate the expression of mRNA encoding PACAP type IA receptor in these cells. Granulosa cells were also cultured in the absence or presence of $100 \mathrm{ng} \mathrm{LH} \mathrm{ml}{ }^{-1}$ with various doses of PACAP-38 $(10,100$ and $1000 \mathrm{ng} \mathrm{ml}^{-1}$ ). At the end of the incubation period, the incubation media were collected and concentrations of progesterone, 20a-hydroxypregn-4-en-3-one (200-OH-P) and CAMP were measured. Increasing concentrations of PACAP-38 significantly stimulated the production of progestins (progesterone and 20a-OH-P) and cAMP accumulation in a dose-dependent manner $(P<0.01$; ANOVA). This effect was observed in media cultured for 24 and $48 \mathrm{~h}$ in both basal and LH-stimulated states. PACAP-38 did not significantly affect the ratio of progesterone: $20 \alpha-\mathrm{OH}-\mathrm{P}$ produced by granulosa cells cultured for $24 \mathrm{~h}$ in the LH-stimulated state. However, at $1000 \mathrm{ng} \mathrm{ml}^{-1}$, PACAP-38 significantly decreased the ratio of progesterone to $20 \alpha-\mathrm{OH}-\mathrm{P}$ production in granulosa cells cultured for $48 \mathrm{~h}$ $(P<0.01)$. These results suggest that granulosa cells from rat ovary express mRNA encoding PACAP type IA receptor and that PACAP may regulate granulosa cell differentiation and play an important role in the reproductive process.
\end{abstract}

\section{Introduction}

Pituitary adenylate cyclase-activating polypeptide (PACAP) was first isolated from ovine hypothalamus by its potent activity to stimulate CAMP production in rat anterior pituitary cells (Miyata et al., 1989). PACAP is a novel member of the secretin-glucagon-vasoactive intestinal polypeptide (VIP)-growth hormone releasing hormone (GHRH) family of peptides (Arimura, 1992). The 28 amino terminal residues of PACAP show $68 \%$ similarity to VIP. Six amino terminal residues of PACAP are identical to residues in GHRH (Miyata et al., 1989). PACAP occurs as two biologically active, amidated forms, PACAP-38 and PACAP-27 (Miyata et al., 1990). Since its isolation, many studies have described PACAP activity in a variety of tissues (Arimura, 1992; Rawlings and Hezareh, 1996). Although the hypothalamus contains the highest concentration of PACAP, the testes also contain significant amounts. In fact, the total PACAP content of both testes is approximately twice that of the total PACAP content of the extrahypothalamic areas of the brain (Arimura et al., 1991). In the testes and epididymides, PACAP type I receptors are localized to Sertoli cells (Heindel et al., 1992) and the tails of spermatozoa (Shivers et al, 1991). mRNA encoding PACAP is also expressed in rat testes (Kononen et al., 1994).

In contrast to the number of studies in testicular tissue, few studies have been made of PACAP expression or function in ovarian tissue. Only small amounts of immunoreactive PACAP-38 and PACAP-27 have been found in ovarian tissue (Arimura et al., 1991). Although Gottschall et al., (1990) observed small amounts of specific binding of ${ }^{125}$ I-labelled PACAP-27 in rat ovary, studies using ${ }^{125}$ I-labelled PACAP and ${ }^{125}$ I-labelled VIP binding have demonstrated that the relative magnitude of binding of these compounds was similar, indicating that this tissue expresses the PACAP type II receptor, which is non-selective since it shows similar high affinity for both PACAP and VIP (Christophe, 1993). There are different receptor subtypes in various cell types (Christophe, 1993). Another PACAP receptor subtype is type I receptor, which is highly selective in that it binds PACAP-38 and PACAP-27 with much greater affinity than it binds related compounds like VIP (Christophe, 1993). Since Zhong and Kasson (1994) reported that PACAP-27- 
stimulated basal and FSH-stimulated steroidogenesis in cultured granulosa cells from diethylstilboestrol (DES)-treated rats, mRNA encoding PACAP type I receptor may be present in granulosa cells.

The present study investigated whether mRNA encoding PACAP type I receptor was present in the granulosa cells of rat ovaries using the techniques of reverse transcription and polymerase chain reaction ( $R T-P C R)$ with primers specific to the PACAP type I receptor. In addition, since Arimura et al. (1991) found that the concentration of immunoreactive PACAP-38 is fourfold higher than the concentration of immunoreactive PACAP-27 in ovarian tissue, the role of PACAP-38 in ovarian preovulatory follicles was examined by using immature rats treated with pregnant mares' serum gonadotrophin (PMSG). This model overcomes the problem of variability in duration of oestrous cycle and the difficulty of obtaining animals at the same stage of the cycle at any given time. Although the exposure to DES does not induce maturational changes in the granulosa cells, as measured by increases in $\mathrm{LH}$ binding capacity (Zeleznik et al., 1974), a moderate dose of PMSG is known to be followed $56 \mathrm{~h}$ later by the discharge of an ovulatory concentration of $\mathrm{LH}$ and by ovulation about $66 \mathrm{~h}$ later (Klawon et al., 1971). Thus, the process of follicular growth is synchronized and granulosa cells from preovulatory follicles are harvested $48 \mathrm{~h}$ after the injection of PMSG. Whether PACAP-38 regulates the production of progestins

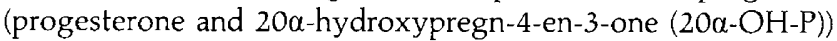
and the accumulation of cAMP in cultured granulosa cells in the basal state and in the LH-stimulated state were also investigated.

\section{Materials and Methods}

\section{Reagents and hormones}

Ovine LH (oLH) was kindly provided by the National Institute of Health (Bethesda, MD). This compound (NIH-LH) is also known as NIADDK-oLH-24 or AFP-0754. NIH-LH has an $\mathrm{LH}$ potency 2.3 times greater than NIH-LH-SI. By weight, the potency of $\mathrm{NIH}-\mathrm{LH}$ is $<0.5 \%$ for $\mathrm{FSH}, 0.1 \%$ for growth hormone, $0.1 \%$ for prolactin, and $<0.5 \%$ for thyroid stimulating hormone. PACAP-38 was purchased from the Peptide Institute (Osaka). PMSG was purchased from TeikokuZoki Co. (Tokyo). Modified TCM 199 was prepared with Medium 199 (1.0\% glucose $(w / v)$, Gibco Life Technologies Inc., New York) supplemented with 0.1\% BSA (Sigma Chemical Co., St Louis, $\mathrm{MO}), 0.22 \%(\mathrm{w} / \mathrm{v}) \mathrm{NaHCO}_{3}, 100 \mu \mathrm{g}$ streptomycin $\mathrm{ml}^{-1}$ and $100 \mathrm{iu}$ penicillin $\mathrm{ml}^{-1}$ (both available from Meijiseika Co., Tokyo). 20a-OH-P was purchased from Sigma Chemical Co. Specific antiserum to $20 \alpha-\mathrm{OH}-\mathrm{P}$ and horseradish peroxidase (HRP)-labelled 20 $\alpha-\mathrm{OH}-\mathrm{P}$ were purchased from Cosmo Bio Co. Ltd (Tokyo). o-Phenylenediamine was purchased from Wako Pure Chemical Industries Ltd (Osaka). Specific PCR primers for the PACAP type I receptor were obtained from Takara Shuzo Co. (Kyoto). $\alpha^{-32}$ P-labelled dCTP (110 TBq $\mathrm{mmol}^{-1}$ ) was obtained from Amersham (Amersham, Bucks).

\section{Animals and treatments}

Immature female rats of the Wistar-Imamichi strain were obtained from the Imamichi Institute for Animal Reproduction
(Ibaraki). These animals were maintained in air-conditioned quarters with a $12 \mathrm{~h}$ light-12 h dark cycle. At 23 days of age, animals were given a subcutaneous injection of 20 iu PMSG. The animals were anaesthetized with ether $48 \mathrm{~h}$ after the injection and decapitated, and the ovaries were then removed.

\section{Harvesting of granulosa cells}

Under aseptic conditions, the ovaries were shelled from their bursae and removed from the oviducts and the adhering fat. The ovaries were washed in Dulbecco's PBS and the granulosa cells were harvested by repeated puncture of the large surface preovulatory follicles with 27 gauge needles. The harvested granulosa cells were transferred to $15 \mathrm{ml}$ conical centrifuge tubes and gathered by centrifugation at $200 \mathrm{~g}$ for $5 \mathrm{~min}$ at room temperature. After centrifugation, the cells were washed with PBS. The cells were counted with a haemocytometer. Viability was assessed by observing the exclusion of Trypan blue dye. The cells were washed and resuspended in modified TCM 199.

\section{Preparation of $m R N A$}

For the detection of mRNA encoding PACAP type I receptor, the granulosa cells were pelleted and snap-frozen in liquid nitrogen. The pelleted cells were stored at $-80^{\circ} \mathrm{C}$ until the RNA could be extracted. Snap-frozen granulosa cells were homogenized. Poly $(\mathrm{A})^{+}$RNA was isolated according to the manufacturer's instructions provided with the mRNA isolation kit purchased from Invitrogen Co. (San Diego, CA). Any DNA contamination was eliminated by purifying the poly $(A)^{+}$RNA sample with amplification grade DNase I (Gibco Life Technologies Inc.). The poly(A) ${ }^{+}$RNA was quantified by measuring the absorbance at $260 \mathrm{~nm}$ in a spectrophotometer.

\section{Reverse transcription and the polymerase chain reaction}

Single stranded complementary DNA (cDNA) was synthesized from the Poly $(A)^{+}$RNA extracted from granulosa cells. The $R T$ reaction was carried out using I $\mu \mathrm{g}$ mRNA as a template in a Takara Shuzo PCR Thermal Cycler. The reaction components were incubated at $42^{\circ} \mathrm{C}$ for $60 \mathrm{~min}$, heated to $99^{\circ} \mathrm{C}$ for $5 \mathrm{~min}$, and flash cooled to $5^{\circ} \mathrm{C}$. A negative control was prepared for the RT reactions. The negative control contained all reagents except the reverse transcriptase enzyme. PCR was carried out according to the RNA PCR Kit instructions (Takara Shuzo Co.). The primers used for the amplification of PACAP type I receptor cDNA correspond to the base sequences of either type IA or type IB of the rat PACAP receptor gene (Hosoya et al., 1993; Fig. 1). The RT product samples and the PACAP type I receptor CDNA were subjected to 40 cycles of amplification in a Takara Shuzo PCR Thermal Cycler with denaturation at $94^{\circ} \mathrm{C}$ for $30 \mathrm{~s}$, primer annealing at $63^{\circ} \mathrm{C}$ for $30 \mathrm{~s}$, and primer extension at $72^{\circ} \mathrm{C}$ for $1.5 \mathrm{~min}$. The reaction products were stored at $4^{\circ} \mathrm{C}$ until gel electrophoresis.

\section{Gel electrophoresis}

The PCR products were extracted in phenol-chloroform solution and subjected to electrophoresis on a $2.0 \%$ agarose gel 


\section{Type IA}
primer 1
$5^{\prime}$-TTTCATCGGCATCATCATCATCCTT- $3^{1042-1066}$
primer 2 5 '-CCTTCCAGCTCCTCCATTTCCTCTT-3 ${ }^{\text {1307-1331 }}$

\section{Type IB}
primer 1
$5^{\prime}$-TTTCATCGGCATCATCATCATCCTT- $3^{1042-1066}$
primer 2
$5^{\prime}$-CCTTCCAGCTCCTCCATTTCCTCTT-3 ${ }^{1391-1415}$

Fig. 1. Design of the rat pituitary adenylate cyclase-activating polypeptide (PACAP) type I receptor polymerase chain reaction oligonucleotide primers. Two oligonucleotide primers were designed to anneal to two subtypes of the rat PACAP receptor CDNA sequence (Hosoya et al., 1993).

stained with ethidium bromide. The DNA was visualized under UV light. The predicted size of the PCR products corresponding to the mRNA encoding PACAP type IA receptor was $290 \mathrm{bp}$. The predicted size of the PCR products corresponding to the mRNA encoding PACAP type $\mathrm{IB}$ receptor was $374 \mathrm{bp}$.

\section{Southern blot analysis}

The PCR products were transferred to nitrocellulose membranes purchased from Schleicher and Schuell (Dassel) according to the method described by Maniatis et al. (1982). The cDNA corresponding to the PACAP type I receptor from rat was cloned according to the method described by Hosoya $e t$ al. (1993). Briefly, cDNA for the PACAP type I receptor was isolated by screening a rat brain CDNA library with a fragment of the rat VIP receptor. The PACAP type IA receptor oligonucleotide probe was a 987 bp Hind III-Pst I fragment from the coding sequence of the rat PACAP type IA receptor cDNA. The oligonucleotide probe was radiolabelled with $\alpha{ }^{32}$ P-labelled dCTP using a multiprime DNA labelling kit (Amersham). Hybridization was carried out overnight at $65^{\circ} \mathrm{C}$ in a hybridization buffer containing $40 \%$ formamide, $1 \%$ Denhardt's solution, $4 \mathrm{SSC}, 0.02 \mathrm{~mol}$ Tris $1^{-1}$ and $20 \mu \mathrm{g}$ heat-denatured salmon sperm DNA ml ${ }^{-1}$. After hybridization, the membranes were washed in a $63^{\circ} \mathrm{C}$ solution of $0.5 \mathrm{SSC}$ and $0.1 \%$ SDS. The membranes were analysed using an Imaging Plate ${ }^{(i)}$ and Image Analyser BAS-2000 (Fuji Film, Tokyo).

\section{Incubation of granulosa cells}

The effect of PACAP on progestin biosynthesis was examined by plating granulosa cells in 24-well tissue culture dishes (Beckton Dickenson, Lincoln Park, NJ) in modified TCM 199 at a final concentration of $5 \times 10^{5}$ viable cells $\mathrm{ml}^{-1}$. In addition to a control group (no treatment) some cells were treated with $100 \mathrm{ng} \mathrm{LH} \mathrm{ml}^{-1}$. Other cells were treated with PACAP-38 at concentrations of 10,100 and $1000 \mathrm{ng} \mathrm{ml}^{-1}$. Additional groups of cells were treated with LH (100 $\mathrm{ng} \mathrm{ml}^{-1}$ ) and $\operatorname{PACAP}\left(10,100\right.$ and $\left.1000 \mathrm{ng} \mathrm{ml}^{-1}\right)$. The final volume in each well was $1 \mathrm{ml}$. The cells were placed in a $37^{\circ} \mathrm{C}$ incubator with a humidified gas mixture of $5 \% \mathrm{CO}_{2}$ and $95 \%$ room air for 24 or $48 \mathrm{~h}$.

\section{Measurement of steroid and $c A M P$}

At the end of the 24 or $48 \mathrm{~h}$ incubation period, the steroid content and the concentration of cAMP were measured in all culture wells. For the measurement of progesterone, samples were collected, frozen, and stored at $-20^{\circ} \mathrm{C}$ until they could be assayed. Progesterone was measured in duplicate samples using an enzymeimmunoassay (EIA) kit (Cayman Chemical Co., Ann Arbor, MI). The crossreactivity of the antiserum used in the progesterone assay was $100 \%$ for progesterone, $61 \%$ for pregnenolone, $7.2 \%$ for oestradiol, and $6.7 \%$ for $5 \beta$-pregnon$3 \alpha$-2-one, and $<0.01 \%$ for other $\mathrm{C} 21$ and $\mathrm{C} 18$ steroids. The minimum detectable amount of the steroid assay was $10.2 \mathrm{pg} \mathrm{ml}^{-1}$.

For the measurement of $20 \mathrm{a}-\mathrm{OH}-\mathrm{P}$, samples were collected, frozen, and stored at $-20^{\circ} \mathrm{C}$ until they could be assayed. The concentration of $20 \alpha-\mathrm{OH}-\mathrm{P}$ was measured using a competitive enzyme immunoassay in duplicate samples. HRP-labelled $20 \alpha-$ $\mathrm{OH}-\mathrm{P}$, specific antiserum to $20 \alpha-\mathrm{OH}-\mathrm{P}$, and either a known standard or an unknown sample were added to microtest plates coated with anti-rabbit IgG and incubated at room temperature for $4 \mathrm{~h}$. After a saline wash, the bound enzyme activity was measured using o-phenylenediamine as a chromogen. After a distinct yellow colour was observed, $3 \mathrm{~mol}$ sulfuric acid $\mathrm{ml}^{-1}$ was added to each well to halt the reaction. The absorbance at $492 \mathrm{~nm}$ was determined in a plate reader. The crossreactivity of the antiserum used in the $20 \alpha-\mathrm{OH}-\mathrm{P}$ assay was $100 \%$ for $20 \alpha$-OH-P, $5 \%$ for $20 \beta$-OH-progesterone, $3.6 \%$ for $17 \alpha, 20 \alpha$ $(\mathrm{OH}) 2$-progesterone, $1.2 \%$ for progesterone, $0.18 \%$ for pregnanediol, $\quad 0.15 \%$ for pregnenolone, $0.07 \%$ for $17 \mathrm{a}-\mathrm{OH}-$ progesterone, $0.05 \%$ for $17 \alpha$-OH-pregnenolone, $0.4 \%$ for $\mathrm{C} 18$ steroids and $0.02 \%$ for oestradiol. The minimum detectable amount was $0.1 \mathrm{ng} \mathrm{ml}^{-1}$.

PACAP stimulates cAMP production in several types of cell (Arimura, 1992; Rawlings and Hezareh, 1996). In granulosa cells, LH increases CAMP concentrations (Marsh, 1975). Therefore, the effect of PACAP on the concentrations of cAMP in cultured granulosa cells both in the basal state and following 


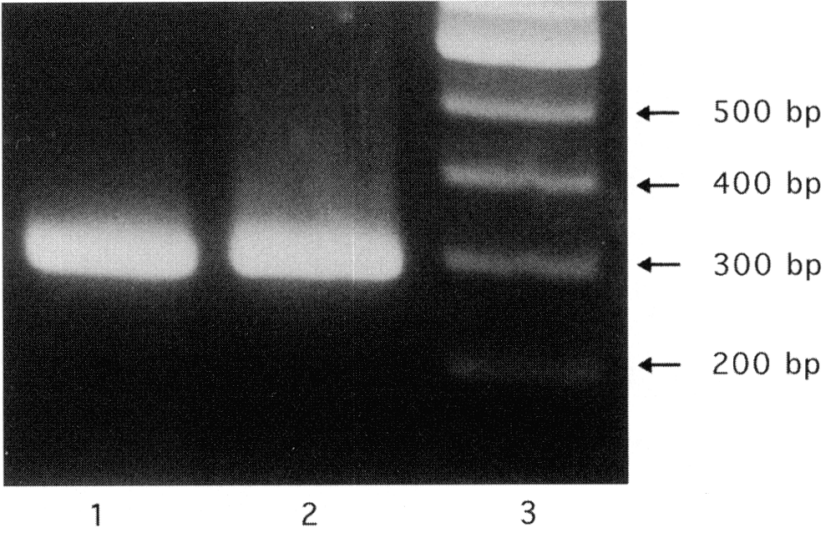

Fig. 2. Reverse transcription and polymerase chain reaction (RT-PCR) of mRNA encoding pituitary adenylate cyclase-activating polypeptide (PACAP) type I receptor from ovarian granulosa cells from immature rats treated with pregnant mares' serum gonadotrophin. mRNA isolated from granulosa cells was reverse transcribed, and the RT product CDNA was amplified for 40 cycles using PACAP type I receptor specific primers. The PCR product DNA was separated by agarose gel electrophoresis and stained with ethidium bromide. Lane 1: RT-PCR product of Poly $(A)^{+}$RNA extracted from granulosa cells; lane 2: PCR product on the CDNA clones encoding rat PACAP type IA receptor; lane 3: molecular weight markers

stimulation with $\mathrm{LH}$ was studied. For measurement of extracellular cAMP, the culture media were boiled for $10 \mathrm{~min}$ at the end of the incubation period to inactivate phosphodiesterases before the samples were frozen and stored at $-20^{\circ} \mathrm{C}$. The concentrations of cAMP were analysed using an enzyme immunoassay kit in duplicate samples according to the manufacturer's instructions (Amersham). The crossreactivity of the antiserum used in the CAMP assay was 100\% for CAMP, $0.03 \%$ for cIMP, $0.02 \%$ for cTMP, and $<0.01 \%$ for cGMP, cCMP, AMP, ADP or ATP. The minimum detectable amount was $0.125 \mathrm{pmol} \mathrm{ml}^{-1}$. Intra-assay and interassay coefficients of variation were $<10 \%$.

\section{Statistical analyses}

The data are presented as the means \pm SEM of four samples from each group: progesterone, 20 $\alpha-\mathrm{OH}-\mathrm{P}$ and cAMP. Comparisons of treatment with different doses of PACAP were performed by one-way analysis of variance (ANOVA), followed by post hoc Dunnett test. Student's t test was used to compare the results between the control group and the LH treatment group.

\section{Results}

\section{mRNA encoding PACAP type I receptor in granulosa cells}

The PCR product yielded only one major band and the molecular weight of the product was 290 bp (Fig. 2). mRNA encoding PACAP receptor subtype IA, but not subtype IB, was present. No bands were generated from the negative control.
Identically prepared Southern blot analyses confirmed that the PCR DNA product corresponded to the PACAP type IA receptor sequence.

\section{Effects of PACAP on the production of progesterone}

The effects of PACAP treatment on progesterone production were evaluated by culturing granulosa cells from rat ovary for $24 \mathrm{~h}$ with various concentrations of PACAP-38 (10, 100 and $1000 \mathrm{ng} \mathrm{ml}^{-1}$ ). PACAP-38 significantly stimulated basal production of progesterone in granulosa cells in a dose-dependent manner $(P<0.01$, ANOVA; Fig. 3a). The PACAP-38-stimulated production of progesterone was significant when the PACAP-38 concentration was equal to 100 and $1000 \mathrm{ng} \mathrm{ml}^{-1}$ compared with control $(P<0.05$ and $P<0.001$, respectively). The effect of PACAP treatment on LH-stimulated progesterone production was determined by treating granulosa cells with both LH (100 ng ml ${ }^{-1}$ ) and PACAP-38 (10, 100 and $1000 \mathrm{ng} \mathrm{ml}^{-1}$ ). After $24 \mathrm{~h}$ of culture, LH significantly enhanced basal progesterone production compared with the LH-untreated control ( $P<0.001$, $t$ test). PACAP-38 significantly increased LH-stimulated progesterone production in a dose-dependent manner $(P<0.01$, ANOVA). Although the increase in $\mathrm{LH}$-stimulated progesterone production with $10 \mathrm{ng}$ PACAP-38 ml $\mathrm{ml}^{-1}$ was not significant, the increases in LH-stimulated progesterone production observed with 100 and $1000 \mathrm{ng}$ PACAP $-38 \mathrm{ml}^{-1}$ were significant $(P<0.01$ and $P<0.001$, respectively).

The effects of PACAP treatment on the production of progesterone in granulosa cells after $48 \mathrm{~h}$ differentiation in culture were also determined. PACAP-38 significantly stimulated basal production of progesterone after $48 \mathrm{~h}$ of culture $(P<0.01$, ANOVA; Fig. 3b). The PACAP-38-stimulated basal production of progesterone was significant when the PACAP-38 concentration was 100 and $1000 \mathrm{ng} \mathrm{ml}^{-1}$ $(P<0.05$ and $P<0.001$, respectively). $\mathrm{LH}$ treatment alone significantly stimulated basal progesterone production compared with the LH-untreated control group $(P<0.001, t$ test). When present at a concentration of $1000 \mathrm{ng} \mathrm{ml}^{-1}$, PACAP-38 significantly increased $\mathrm{LH}$-stimulated progesterone production $(P<0.01)$.

\section{Effects of PACAP on the production of 20a-OH-P}

The effect of PACAP on the production of $20 \alpha-\mathrm{OH}-\mathrm{P}$ was also determined (20a-OH-P is a product of irreversible metabolism of progesterone). In granulosa cells cultured for $24 \mathrm{~h}$, PACAP-38 significantly stimulated basal $20 \alpha-\mathrm{OH}-\mathrm{P}$ production in a dose-dependent manner $(P<0.01$, ANOVA; Fig. 4a).

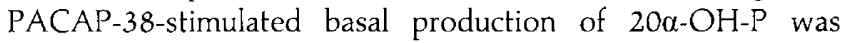
significant when the PACAP-38 concentration was 100 and $1000 \mathrm{ng} \mathrm{ml}^{-1}$ ( $P<0.05$ and $P<0.001$, respectively). In granulosa cells cultured for $24 \mathrm{~h}, \mathrm{LH}$ also significantly increased basal $20 \alpha-\mathrm{OH}-\mathrm{P}$ production $(P<0.001, t$ test). Increasing concentrations of PACAP-38 produced progressively larger increases in LH-stimulated $20 \alpha-\mathrm{OH}-\mathrm{P}$ production $(P<0.001$, ANOVA). When the concentration of PACAP-38 was 100 or $1000 \mathrm{ng} \mathrm{ml}^{-1}$, the PACAP-38 enhancement of LH-stimulated 

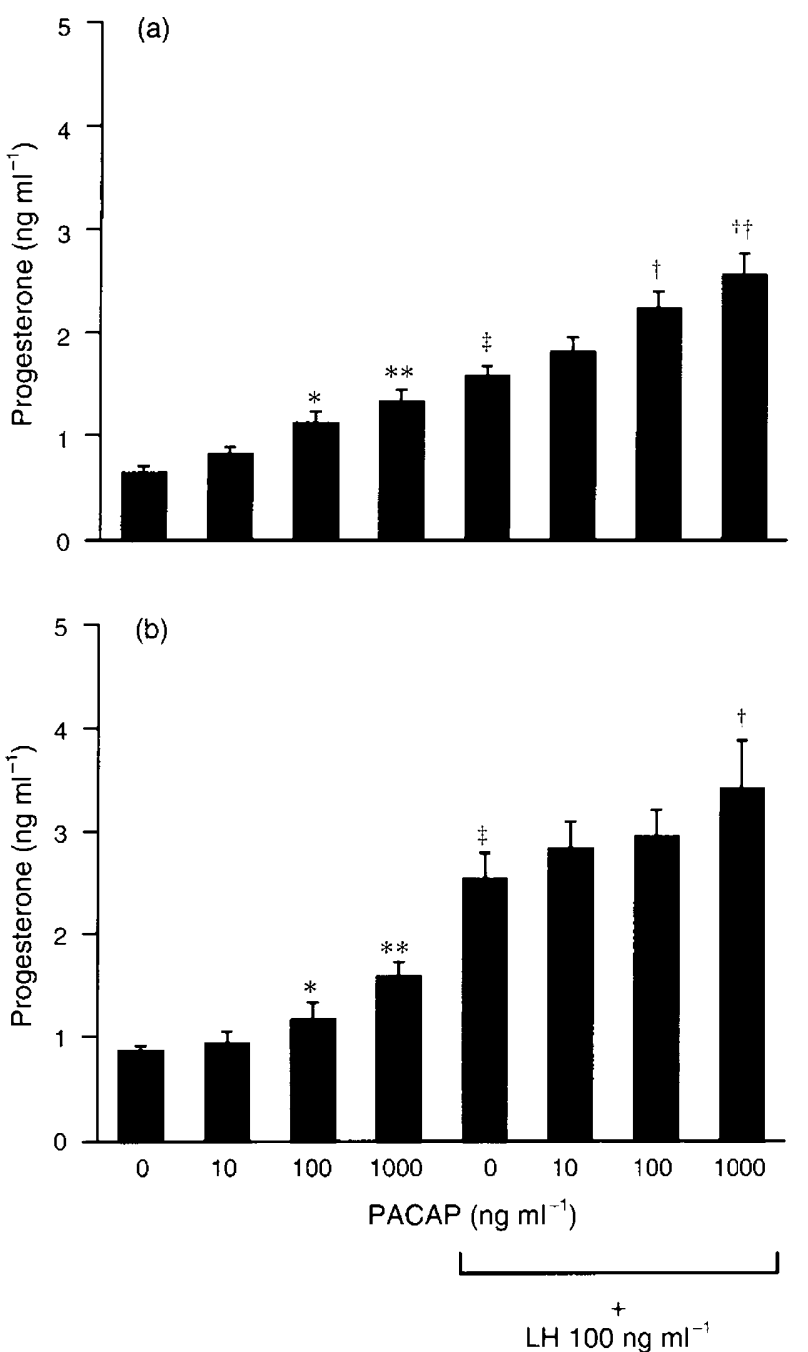

Fig. 3. Effects of pituitary adenylate cyclase-activating polypeptide (PACAP) on the production of progesterone in cultured ovarian granulosa cells from immature rats treated with pregnant mares' serum gonadotrophin. Granulosa cells were cultured with PACAP-38 and $\mathrm{LH}$. Cells were cultured for (a) $24 \mathrm{~h}$ or (b) $48 \mathrm{~h}$. Progesterone concentrations were assayed. Values are means \pm SEM for four cultures performed in duplicate. ${ }^{*} P<0.05$ and ${ }^{*}{ }^{*} P<0.001$, respectively, compared with the hormone-untreated control group; ${ }^{\dagger} P<0.01$ and ${ }^{\dagger+} P<0.001$, respectively compared with LH treatment alone (one-way ANOVA followed by a Dunnett test); ${ }^{\ddagger} P<0.001$ compared with the hormone-untreated control group (Student's $t$ test).

$20 \alpha-\mathrm{OH}-\mathrm{P}$ production was significant $(P<0.01$ and $P<0.001$, respectively) compared with treatment with $\mathrm{LH}$ alone.

In granulosa cells cultured for $48 \mathrm{~h}$, the stimulation of basal $20 \alpha-\mathrm{OH}-\mathrm{P}$ production was significant when the concentration of PACAP-38 was $1000 \mathrm{ng} \mathrm{ml}^{-1}(P<0.05$; Fig. $4 \mathrm{~b})$. LH treatment alone also significantly stimulated basal progesterone production $(P<0.001, t$ test). Although the increase in LH-stimulated $20 \alpha-\mathrm{OH}-\mathrm{P}$ production with $10 \mathrm{ng}$ PACAP-38 $\mathrm{ml}^{-1}$ was not significant, compared with LH treatment alone, the increases in LH-stimulated 20a-OH-P production observed with 100 and $1000 \mathrm{ng}$ PACAP-38 ml ${ }^{-1}$ were significant $(P<0.05$ and $P<0.05$, respectively).
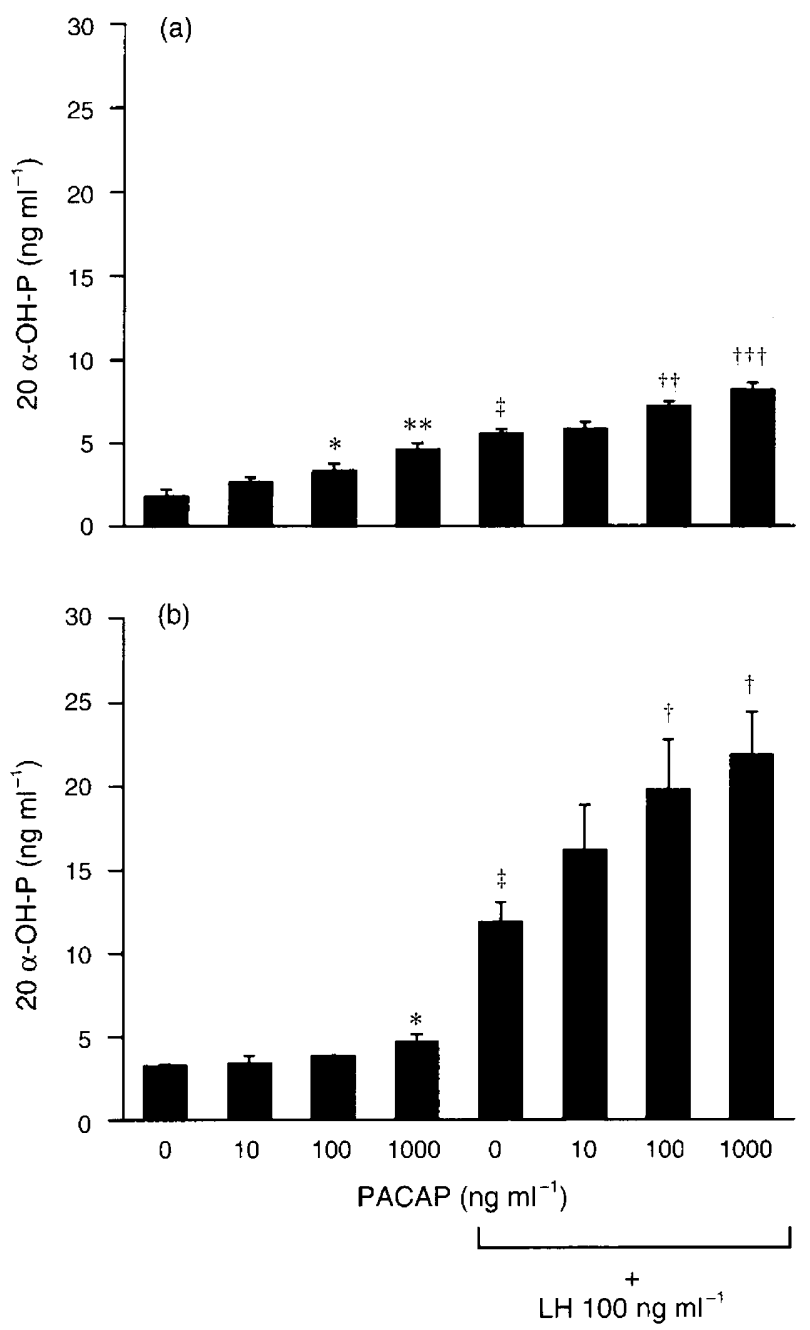

Fig. 4. Effects of pituitary adenylate cyclase-activating polypeptide

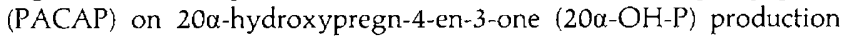
in cultured granulosa cells from the ovaries of immature rats treated with pregnant mares' serum gonadotrophin. Values are means \pm SEM for four cultures performed in duplicate. $* P<0.05$ and $* * P<0.001$, respectively, compared with the hormone-untreated control group; ${ }^{\dagger} P<0.05,{ }^{\dagger \dagger} P<0.01,{ }^{+\dagger+} P<0.001$, respectively, compared with $\mathrm{LH}$ treatment alone (one-way ANOVA followed by a Dunnett test); ${ }^{ \pm} P<0.001$ compared with the hormone-untreated control group (Student's $t$ test).

\section{Effects of PACAP on $C A M P$ accumulation}

The effect of PACAP on the accumulation of cAMP in cultured granulosa cells both in the basal state and after stimulation with $\mathrm{LH}$ was investigated. After $24 \mathrm{~h}$ incubation, PACAP-38 significantly stimulated basal cAMP accumulation in a dose-dependent manner $(P<0.001$, ANOVA; Fig. 5a). The PACAP-38-stimulated increases in basal CAMP accumulation were significant at all concentrations of PACAP-38 studied (10, 100 and $1000 \mathrm{ng} \mathrm{ml}^{-1} ; P<0.05, P<0.001$ and $P<0.001$, respectively). In granulosa cells cultured for $24 \mathrm{~h}$, LH stimulation also significantly increased basal cAMP accumulation $(P<0.001, t$ test $)$. PACAP-38 significantly stimulated $\mathrm{LH}$ dependent increases in cAMP accumulation and this effect was dose-dependent $(P<0.001$, ANOVA $)$. Compared with $\mathrm{LH}$ 

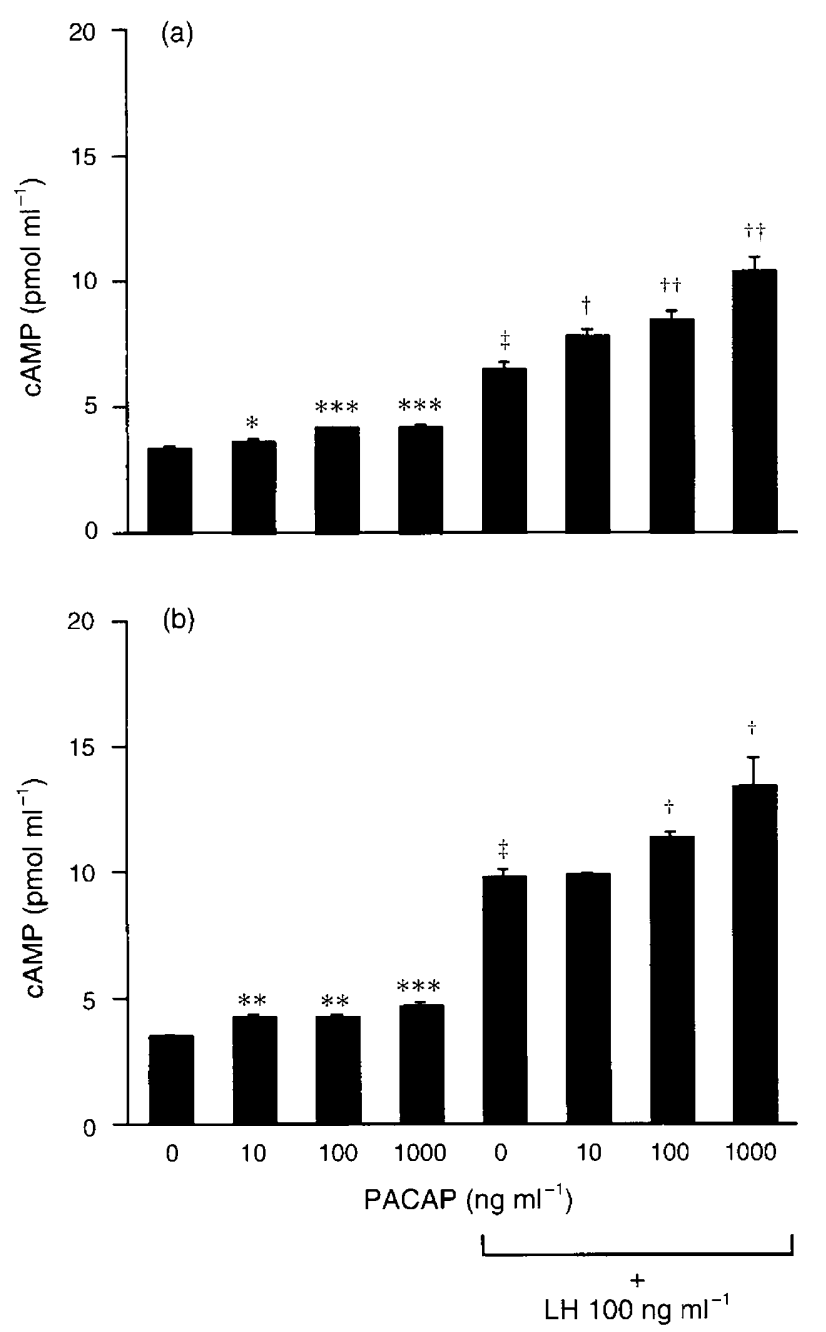

Fig. 5. Effects of pituitary adenylate cyclase-activating polypeptide (PACAP) on cAMP accumulation in cultured granulosa cells from the ovaries of immature rats treated with pregnant mares' serum gonadotrophin. Values are means \pm SEM for four cultures performed in duplicate. ${ }^{*} P<0.05, * * P<0.01$ and ${ }^{* * *} P<0.001$, respectively, compared with the hormone-untreated control group; ${ }^{\dagger} P<0.01$ and ${ }^{+t} P<0.001$, respectively, compared with LH treatment alone (oneway ANOVA followed by a Dunnett test); ${ }^{\ddagger} P<0.001$ compared with the hormone-untreated control group (Student's $t$ test).

treatment alone, PACAP-38 enhancement of LH-stimulated CAMP accumulation was significant at all concentrations of PACAP-38 studied (10, 100 and $1000 \mathrm{ng} \mathrm{ml}^{-1} ; P<0.01$, $P<0.001$ and $P<0.001$, respectively).

In granulosa cells cultured for $48 \mathrm{~h}$, PACAP-38 significantly stimulated basal cAMP accumulation in a dose-dependent manner $(P<0.01$, ANOVA; Fig. 5b). The PACAP-38stimulated increases in basal cAMP accumulation were significant at all concentrations of PACAP-38 studied (10, 100 and $1000 \mathrm{ng} \mathrm{ml}^{-1} ; P<0.01, P<0.01$ and $P<0.001$, respectively). In granulosa cells cultured for $48 \mathrm{~h}$, LH stimulation also significantly increased basal cAMP accumulation $(P<0.001$, it test). PACAP-38 significantly stimulated LH-dependent increases in CAMP accumulation and this effect was dosedependent $(P<0.01$, ANOVA). Compared with LH treatment alone, PACAP-38 enhancement of LH-stimulated cAMP accumulation was significant when the concentrations of PACAP-38 studied were 100 and $1000 \mathrm{ng} \mathrm{ml}^{-1}(P<0.01$ and $P<0.01$, respectively).

\section{Discussion}

PACAP and VIP share receptors in a variety of tissue types (Christophe, 1993). At least two classes of PACAP receptors have been described in mammalian tissues and cell lines: type I PACAP-preferring receptors and type II receptors (Christophe, 1993). Tissues can contain various proportions of PACAP type I and type II receptor. Binding studies of whole ovaries suggest that they contain PACAP type II receptors (Gottschall et al., 1990). From this, it might be predicted that PACAP and VIP would produce similar responses in this cell type. However, Zhong and Kasson (1994) reported a marked difference between PACAP-27 and VIP in their potency to cause steroidogenesis in cultured rat granulosa cells. Explanations for this finding include the suggestions that PACAP and VIP may interact with the PACAP type II receptor when the receptor is in different conformational states, causing the coupling with PACAP to be more effective in postreceptor signal transduction systems or, alternatively, that granulosa cells contain the more specific PACAP type I receptor (Zhong and Kasson, 1994). Therefore, the present study investigated whether the mRNA encoding PACAP type I receptor was expressed in rat granulosa cells.

PACAP type I receptors can be further classified into type IA or IB (Rawlings and Hezareh 1996). PACAP type I receptor subtypes were identified by choosing primers so that the DNA PCR products would contain the regions that distinguished the receptor subtypes. The expression of $\mathrm{mRNA}$ encoding PACAP type IA receptor in granulosa cells was confirmed using RT-PCR to amplify the mRNA which is expressed in small amounts. Although rat PACAP type IA receptor has $58.8 \%$ sequence similarity to rat VIP receptor (Hosoya et al, 1993), the primers used in the present study did not anneal to either the VIPI receptor or the VIP2 receptor (Ishihara et al., 1992; Hosoya ef al., 1993; Lutz et al., 1993). Therefore, the PCR products in the present study were derived from mRNA encoding PACAP type I receptor and not from mRNA encoding type II (VIP) receptor.

The mechanism by which PACAP-38 affects the concentration of progestin biosynthesis in cultured granulosa cells from PMSG-treated rats was investigated. In the ovaries of immature rats treated with PMSG, progesterone is rapidly reduced to $20 \alpha-\mathrm{OH}-\mathrm{P}$ (Leerner and Eckstein, 1978). In principle, increased progesterone production may reflect either enhanced biosynthesis or diminished catabolism to metabolites such as

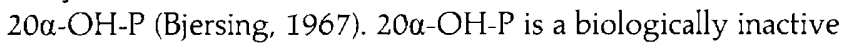
proximate metabolite of progesterone. The present study demonstrated that, in cultured granulosa cells, PACAP-38 significantly stimulated the production of progesterone and $20 \alpha-\mathrm{OH}-\mathrm{P}$ at all concentrations of PACAP-38 studied $(10,100$ and $1000 \mathrm{ng} \mathrm{ml}^{-1}$ ) in a dose-dependent manner. These results suggest that PACAP-38 modulates progesterone formation or degradation, or both. Wang et al. (1981) demonstrated that LH stimulates progestin production in cultured granulosa cells 
from rat ovaries. The effect of PACAP on LH-stimulated progestin production in granulosa cells cultured with LH (100 $\mathrm{ng} \mathrm{ml} \mathrm{ml}^{-1}$ ) alone, or in combination with PACAP-38, was examined. LH treatment alone significantly stimulated progesterone and $20 \alpha-\mathrm{OH}-\mathrm{P}$ production. PACAP-38 enhanced LH-stimulated progestin production, suggesting that PACAP-38 may augment the ability of $\mathrm{LH}$ to induce the differentiation of granulosa cells in culture. In granulosa cells cultured for $24 \mathrm{~h}$ with LH, PACAP-38 did not affect the ratio of progesterone: $20 \alpha-O H-P$. In granulosa cells cultured for $48 \mathrm{~h}$ with LH, PACAP-38 decreased the ratio of progesterone: $20 \alpha-O H-P$. These results suggest that, with longer culture times, PACAP-38 may be more important to progesterone degradation than formation and that PACAP-38 may stimulate $20 \alpha$-hydroxysteroid dehydrogenase synthesis or activity in the granulosa cell. Although the change in steroid secretion pattern with duration of culture may reflect induction of PACAP receptor in vitro, further studies will be needed to confirm this hypothesis, including binding study or quantitative RT-PCR of cultured granulosa cells.

cAMP is a second messenger that mediates the action of LH on gonadal steroid production. LH augments cAMP accumulation, an action that may reflect enhanced adenylate cyclase activity (Marsh, 1975). In the present study, PACAP-38 stimulated basal and LH-stimulated cAMP accumulation. This effect has also been reported in other cell types (Arimura, 1992; Rawlings and Hezareh, 1996). PACAP-38 stimulated cAMP accumulation in a dose-dependent manner over the range of concentrations that also stimulated progestin biosynthesis. Several groups have reported that CAMP and dibutyryl cAMP induce granulosa cells to synthesize progestin (Channing and Seymour, 1970; Marsh, 1975). The present data suggest that PACAP-38-augmented biosynthesis of progestin in granulosa cells may be associated with enhanced production of cAMP.

PACAP type II receptors have also been described in rat ovary (Gottschall et al., 1990). This raises the question whether the effects observed in the present study were exerted by PACAP actions through these receptors. Zhong and Kasson (1994) reported that PACAP-27 stimulates steroidogenesis and cAMP accumulation in cultured granulosa cells and that it is more potent than VIP and GHRH. The same results were obtained in the present study (data not shown). Heindel et al. (1996) reported that granulosa cells from DES-treated immature rats respond similarly to PACAP-38 and PACAP-27 with regard to cAMP accumulation. Type IA receptor binds PACAP-38 and PACAP-27 with approximately equal affinity, and type $\mathrm{IB}$ receptor has an approximately 100 times greater affinity for PACAP-38 than PACAP-27 (Rawlings and Hezareh, 1996). These findings indicate that PACAP may be involved in granulosa cell function via interaction with the PACAP type IA receptor.

The amount of immunoreactive PACAP-38 found in ovary using the specific radioimmunoassay was only $2.00 \pm$ $0.22 \mathrm{ng} \mathrm{g}^{-1}$ wet tissue (Arimura et al., 1991). This is less than the corresponding minimum concentration of PACAP-38 that was required to produce an effect $\left(10 \mathrm{ng} \mathrm{ml}^{-1}\right)$. However, Gräs et al. (1996) reported that PACAP positive cells were observed during the preovulatory and ovulatory period in rats, and also that both mRNA encoding PACAP and PACAP immunoreactivity were detected by in situ hybridization and by immunohistochemistry in granulosa and cumulus cells from preovulatory follicles. These findings suggest that, in granulosa cells, PACAP is synthesized locally and may act as an autocrine or as a paracrine agent. As Zhong and Kasson (1994) pointed out, in their study, the concentrations of PACAP reported were obtained in whole ovarian extracts from adult animals whose cycle stage had not been documented. Arimura et al. (1991) did not localize PACAP to sites within the ovary. Furthermore, in their study, variations in PACAP concentrations that would be expected to occur during the oestrous cycle were not examined.

In summary, mRNA encoding PACAP type IA receptor is expressed in rat granulosa cells, suggesting that the PACAP type IA receptor is synthesized by granulosa cells within the ovary. In addition, PACAP-38 alone was shown to stimulate progestin biosynthesis in granulosa cells, and to enhance LH-stimulated production of progestin. These results suggest that PACAP may be important to the differentiation of granulosa cells in vivo, and that it may regulate gonadotrophin action in preovulatory follicles.

The authors thank the Hormone Distribution Office (NIADDK, $\mathrm{MD}, \mathrm{USA}$ ) for providing ovine $\mathrm{LH}(\mathrm{NIH}-\mathrm{LH}-24)$ and $\mathrm{H}$. Onda, the Director of the Discovery Research Laboratories I (Takeda Chemical Industries Ltd., Ibaraki, Japan), for his valuable advice and guidance. This work was supported in part by Grants-In-Aid for Scientific Research from the Ministry of Education, Science, Sports and Culture of Japan (C-05671351, C-07671900, and C-08671865), and by grants for research from The Foundation for Growth Science in Japan (1995 and 1997).

\section{References}

Arimura A (1992) Pituitary adenylate cyclase activating polypeptide (PACAP): discovery and current status of research Regulatory Peptides 37 287-303

Arimura A, Somogyvári-Vigh A, Miyata A, Mizuno K, Coy DH and Kitada C (1991) Tissue distribution of PACAP as determined by RIA: highly abundant in the rat brain and testes Endocrinology 129 2787-2789

Bjersing L (1967) On the morphology and endocrine function of granulosa cells in ovarian follicles and corpora lutea Acta Endocrinologica (Suppement 125; Copenhagen) 56 1-23

Channing CP and Seymour JF (1970) Effects of dibutryl cyclic-3', 5'-AMP and other agents upon luteinization of porcine granulosa cells in culture Endocrinology 87 165-169

Christophe I (1993) Type I receptors for PACAP (a neuropeptide even more important than VIP?) Biochimica et Biophysica Acta 1154 183-199

Gottschall PE, Tatsuno I, Miyata A and Arimura A (1990) Characterization and distribution of binding sites for the hypothalamic peptide, pituitary adenylate cyclase-activating polypeptide Endocrinology $127 \quad 272-277$

Gräs S, Hannibal J, Georg B and Fahrenkrug J (1996) Transient periovulatory expression of pituitary adenylate cyclase activating peptide in rat ovarian cells Endocrinology 137 4779-4785

Heindel JJ, Powell CJ, Paschall CS, Arimura A and Culler MD (1992) A novel hypothalamic peptide, pituitary adenylate cyclase activating polypeptide, modulates Sertoli cell function in vitro. Biology of Reproduction 47 800-806

Heindel JJ, Sneeden J, Powell CJ, Davis B and Culler MD (1996) A novel hypothalamic peptide, pituitary adenylate cyclase activating polypeptide, regulates the function of rat granulosa cells in vitro. Biology of Reproduction $54523-530$

Hosoya M, Onda H, Ogi K, Masuda Y, Miyamoto Y, Ohtaki T, Okazaki H, Arimura $A$ and Fujino $\mathbf{M}$ (1993) Molecular cloning and functional expression of rat cDNAs encoding the receptor for pituitary adenylate cyclase activating polypeptide (PACAP) Biochemical and Biophysical Research Communications $194133-143$

Ishihara T, Shigemoto R, Mori K, Takahashi K and Nagata S (1992) Functional expression and tissue distribution of a novel receptor for vasoactive intestinal polypeptide Neuron $\mathbf{8} 811-819$ 
Klawon DL, Sorrentino S, Jr and Schalch DS (1971) Plasma luteinizing hormone dynamics in pregnant mare serum-induced ovulators as measured by radioimmunoassay: influence of testosterone Endocrinology 88 1131-1135

Kononen J, Paavola M, Penttilä T-L, Parvinen M and Pelto-Huikko M (1994) Stage-specific expression of pituitary adenylate cyclase activating polypeptide (PACAP) mRNA in the rat seminiferous tubules Endocrinology 135 2291-2294

Leerner N and Eckstein B (1978) Changes in steroidogenesis in preovulatory rat ovaries induced to ovulate with pregnant mare serum gonadotropin Endocrinology 103 1039-1047

Lutz EM, Sheward WJ, West KM, Morrow JA, Fink G and Harmar AJ (1993) The VIP2 receptor: molecular characterization of a CDNA encoding a novel receptor for vasoactive intestinal polypeptide FEBS letters 334 3-8

Maniatis T, Fritsch EF and Sambrook J (1982) Analysis of recombinant DNA clones. In Molecular Cloning: a Laboratory Manual pp 382-386 Cold Spring Harbor Laboratory Press, New York

Marsh JM (1975) The role of cyclic AMP in gonadal function Advances in Cyclic Nucleotide Research 6 137-199

Miyata A, Arimura A, Dahl RR, Minamino N, Uehara A, Jiang L, Cullar MD and Coy DH (1989) Isolation of a novel 38 residue-hypothalamic polypeptide which stimulates adenylate cyclase in pituitary cells Biochemical and Biophysical Research Communications 164 567-574
Miyata A, Jiang L, Dahl RD, Kitada C, Kubo K, Fujino M, Minamino N and Arimura A (1990) Isolation of a neuropeptide corresponding to the $N$-terminal 27 residues of the pituitary adenylate cyclase activating polypeptide with 38 residues (PACAP38) Biochemical and Biophysical Research Communications $170643-648$

Rawlings SR and Hezareh M (1996) Pituitary adenylate cyclase-activating polypeptide (PACAP) and PACAP/vasoactive intestinal peptide receptors: actions on the anterior pituitary gland Endocrine Reviews 17 4-29

Shivers BD, Görcs T], Gottschall PE and Arimura A (1991) Two high affinity binding sites for pituitary adenylate cyclase activating polypeptide have different tissue distributions Endocrinology 128 3055-3065

Wang C, Hsueh AJW and Erickson GF (1981) LH stimulation of estrogen secretion by cultured rat granulosa cells Molecular and Cellular Endocrinology $24 \quad 17-28$

Zeleznik AJ, Midgley AR, Jr and Reichert LE, Jr (1974) Granulosa cell maturation in the rat: increased binding of human chorionic gonadotropin following treatment with follicle-stimulating hormone in vivo. Endocrinology 95 $818-825$

Zhong Y and Kasson BG (1994) Pituitary adenylate cyclase-activating polypeptide stimulates steroidogenesis and adenosine $3^{\prime}, 5^{\prime}$-monophosphate accumulation in cultured rat granulosa cells Endocrinology 135 207-213 